\title{
Musculoskeletal Disorder pada Ekstremitas Atas akibat Penggunaan Telepon Cerdas secara Aktif pada Remaja Pelajar SMA
}

\author{
Arondino P. Darmawan, ${ }^{1}$ Diana V. D. Doda, ${ }^{2}$ Ivony M. Sapulete ${ }^{2}$
}

\author{
${ }^{1}$ Program Studi Pendidikan Dokter Fakultas Kedokteran Universitas Sam Ratulangi Manado \\ ${ }^{2}$ Bagian Fisiologi Fakultas Kedokteran Universitas Sam Ratulangi Manado \\ Email: arondinod@yahoo.co.id; vandadoda@unsrat.ac.id
}

\begin{abstract}
Advances in technological development have led to increased use of smartphones. To date, the prevalence of musculoskeletal disorder (MSD) of the upper extremities is increasing and according to previous studies one of the MSD causes is the continued use of smart phones by high school students. This study was aimed to determine the prevalence of MSD of the upper extremities experienced in the last 7 days and to evaluate the relationship between MSD complaints and smartphone usage among adolescent high school students. This was an analytical study with a cross-sectional design. The instruments in this study were demographic questionnaire, smartphone usage, and modified Nordic Body Map Questionaire. Data were analyzed by using the Spearman Rho correlation test. There were 170 respondents $(\mathrm{N}=170)$ involved in this study. Most of the MSD complaints were in the neck $(\mathrm{n}=73 ; 42.9 \%)$, followed by in the shoulder $(\mathrm{n}=$ $61 ; 35.9 \%)$, and finger $(n=49 ; 28.8 \%)$. Most of the pain was categorized as mild pain. The Spearman Rho test showed significant correlations, as follows: between MSD in the neck and gaming as well as chat frequency $(\mathrm{p}=0.040)$; between MSD in the upper arm and one sesion gaming duration ( $\mathrm{p}=0.005)$; and between MSD in the fingers and gaming duration in one sesion $(\mathrm{p}=0.007)$ and in a day $(\mathrm{p}=0.042)$. In conclusion, among adolescent high school students, frequency as well as duration of smartphone usage could influence the occurrence of MSD in the upper extremities.
\end{abstract}

Keywords: musculoskeletal disorder, smartphone, duration of usage, frequency of usage, gaming

Asbtrak: Kemajuan perkembangan teknologi menyebabkan peningkatan penggunaan telepon cerdas. Prevalensi musculoskeletal disorder (MSD) dari ekstremitas atas meningkat dan menurut penelitian salah satu penyebabnya ialah akibat penggunaan berkelanjutan dari telepon cerdas oleh remaja. Penelitian ini bertujuan untuk mengetahui prevalensi MSD pada ekstremitas atas yang dialami dalam 7 hari terakhir dan mengevaluasi hubungan antara keluhan MSD dengan penggunaan smartphone pada remaja pelajar SMA. Jenis penelitian ialah analitik dengan desain potong lintang. Penelitian ini menggunakan kuesioner demografi, smartphone, dan modifikasi dari Nordic Body Map Questionnaire. Analisis statistik menggunakan tes korelasi Spearman Rho. Hasil penelitian mendapatkan 170 responden $(\mathrm{N}=170)$. Keluhan MSD paling sering dirasakan pada leher $(n=73 ; 42,9 \%)$, bahu $(n=61 ; 35,9 \%)$, dan jari tangan $(n=49 ; 28,8 \%)$. Karakteristik keparahan nyeri yang dirasakan sebagian besar merupakan nyeri ringan. Uji korelasi Spearman Rho mendapatkan korelasi bermakna antara: keluhan MSD pada leher yang dialami dalam 7 hari terakhir dengan frekuensi gaming dan frekuensi chatting $(\mathrm{p}=0,040)$; keluhan MSD pada lengan atas dengan durasi gaming satu sesi $(\mathrm{p}=0,005)$; dan keluhan MSD pada jari tangan dengan durasi gaming dalam satu sesi $(\mathrm{p}=0,007)$ dan dalam sehari $(\mathrm{p}=0,042)$. Simpulan penelitian ini ialah frekuensi dan durasi penggunaan telepon cerdas berpengaruh terhadap timbulnya keluhan MSD ekstremitas atas pada remaja pelajar SMA.

Kata kunci: musculoskeletal disorder, telepon cerdas, durasi, frekuensi, gaming 


\section{PENDAHULUAN}

Penggunaan telepon cerdas memperlihatkan peningkatan sejalan dengan kemajuan perkembangan teknologi. Saat ini di dunia terdapat 2,71 miliar orang yang menggunakan telepon cerdas. Indonesia saat ini menduduki posisi keenam dengan jumlah 67.570.000 pengguna. ${ }^{1}$

Di negara maju seperti Amerika Serikat, pada tahun 2018 penelitian oleh Pew Research Center menemukan bahwa 95\% remaja telah memiliki telepon cerdas, $45 \%$ mengatakan bahwa mereka selalu aktif di internet, dan media sosial yang paling sering digunakan ialah YouTube, Facebook, Instagram, Snapchat, dan Twitter ditambah dengan $90 \%$ remaja memainkan permainan/ video gaming. ${ }^{2}$ Penelitian yang dilakukan firma penelitian di marketing pada tahun 2016 dengan responden sebanyak 1400 orang, melaporkan 245 pengguna telepon cerdas pada kelompok usia di bawah 18 tahun dan 616 pengguna telepon cerdas pada kelompok usia 18-24 tahun. ${ }^{3}$

Telepon cerdas memiliki banyak dampak positif dan negatif. Fungsionalitas merupakan dampak positif dari telepon cerdas secara keseluruhan. Telepon cerdas juga digunakan sebagai media komunikasi yang dapat digunakan di mana dan kapan saja, media mobile payment, dan media pendukung dari aplikasi yang dapat digunakan untuk pendidikan dan kesehatan. ${ }^{4}$ Dari sudut pandang dampak negatif, telepon cerdas berpeluang memberikan efek yang kurang baik pada kesehatan tubuh, salah satunya ialah musculoskeletal disorder (MSD). 5,6

Musculoskeletal disorder (MSD) merupakan kelompok gangguan dan cedera yang memengaruhi sistem muskuloskeletal dan pergerakan tubuh manusia. Gangguan ini dapat terjadi ketika salah satu dari bagian tubuh dipaksa untuk bekerja lebih keras, diregangkan berlebihan, atau digunakan lebih dari fungsinya. Trauma sebagai dampak dari gangguan atau cedera yang terjadi dapat muncul dengan segera, namun jika hal ini terjadi berulang dapat terjadi kerusakan pada periode waktu tertentu. ${ }^{7}$ Insidensi MSD dari ekstremitas atas meningkat akibat penggunaan yang berkepanjangan, dipaksa- kan dan berulang dari berbagai piranti yang digenggam. ${ }^{8}$ Gerakan menggenggam yang berkelanjutan, terlalu lama dan berulang telah diidentifikasi menjadi faktor risiko yang dapat menyebabkan gangguan MSD. ${ }^{9}$

Penelitian Berolo et $\mathrm{al}^{10}$ mengenai keluhan MSD pada perangkat genggam seluler (mobile handheld devices) mendapatkan bahwa dari 140 peserta penelitian ditemukan $84 \%$ peserta yang mengalami nyeri pada setidaknya satu bagian tubuh dengan nyeri pangkal jempol sebagai nyeri yang paling sering muncul pada tangan kiri maupun tangan kanan. Demikian pula penelitian Balakrishan et $\mathrm{al}^{7}$ yang dilakukan pada 200 sampel pengguna telepon cerdas di Asia Metropolitan University mendapatkan $3,5 \%$ sampel merasakan adanya worst possible pain, $24,5 \%$ mengalami moderate pain, $44,5 \%$ mengalami mild pain, dan $24 \%$ tidak merasakan adanya nyeri. Dari data yang tersedia dapat dianalisis bahwa kebiasaan dalam penggunaan telepon cerdas sebagai salah satu piranti/gawai yang digenggam merupakan faktor penting dalam terjadinya keluhan MSD.

Sesuai dengan survei awal yang dilakukan di salah satu kelas dari SMA swasta di Kota Manado, ditemukan bahwa sebagian besar pengguna telepon cerdas mengalami adanya keluhan ketidaknyamanan saat sedang maupun setelah menggunakan telepon cerdas. Melalui uraian di atas, maka penulis tertarik untuk meneliti prevalensi keluhan MSD ekstremitas atas akibat penggunaan telepon cerdas pada pelajar SMA di Kota Manado serta hubungan antara keduanya, terutama hubungan antara penggunaan secara aktif untuk keperluan bermain permainan/gaming dengan keluhan MSD pada ekstremitas atas.

\section{METODE PENELITIAN}

Penelitian ini dilaksanakan di SMA Katolik Rex Mundi Manado dengan peserta penelitian yang terdiri dari 7 kelas. Jenis penelitian ialah analitik dengan desain potong lintang.

Setelah mengisi lembar persetujuan (informed consent), responden diminta untuk mengisi kuesioner yang terdiri dari 
data identitas, lembar kuesioner tentang frekuensi dan durasi penggunaan telepon genggam, dan kuisioner Modified Nordic Questionnaire untuk mengetahui prevalensi keluhan MSD. ${ }^{11}$ Pertanyaan meliputi keluhan MSD dari ekstremitas atas yang dialami dalam 7 hari terakhir.

Pada penelitian ini, kriteria inklusi yang digunakan ialah semua yang memiliki dan menggunakan telepon cerdas, sedangkan yang menjadi kriteria eksklusi ialah yang memiliki riwayat cedera muskuloskeletal maupun deformitas pada ekstremitas atas, riwayat cedera neurologis lainnya pada ekstremitas atas, dan merupakan atlit badminton, tenis, maupun tenis meja.

Sebanyak 220 kuesioner dibagikan pada responden, tetapi hanya 170 kuesioner dianggap memenuhi kriteria. Data yang didapat kemudian diolah menggunakan aplikasi statistik. Untuk mengetahui adanya hubungan antara keluhan MSD pada esktremitas atas yang dialami dalam 7 hari terakhir dan aktivitas bermain permainan/gaming, dilakukan uji korelasi Spearman.

\section{HASIL PENELITIAN}

Hasil penelitian mendapatkan 170 orang responden terdiri dari $62,9 \%$ pelajar perempuan dan sisanya merupakan pelajar laki-laki. Berdasarkan karakteristik usia, didapatkan bahwa usia rerata subjek penelitian ialah 14,7 tahun dengan subjek penelitian termuda berusia 13 tahun dan yang tertua berusia 16 tahun. Subyek yang terbanyak berusia 15 tahun $(n=109 ; 64,1 \%)$. Tabel 1 memperlihatkan bahwa $79,5 \%$ secara aktif memiliki akvitas bermain permainan/gaming.

Tabel 2 memperlihatkan bahwa pada 135 subjek yang memiliki aktivitas bermain permainan/gaming dengan telepon cerdas didapatkan frekuensi aktivitas bermain minimal dan maksimal masing-masing sebanyak 1 kali dan 10 kali dalam sehari dengan rerata frekuensi sehari sebanyak 2,9 kali. Selanjutnya, pada data durasi dalam satu sesi bermain permainan ditemukan durasi minimal selama 5 menit $(0,08$ jam $)$ dan durasi maksimal selama 5 jam dengan durasi rerata selama 1,6 jam. Pada durasi bermain permainan dalam sehari, ditemukan total durasi minimal selama 15 menit $(0,25$ jam) dan total durasi maksimal selama 15 jam dengan rerata total durasi 4,5 jam.

Hasil penelitian dengan kuesioner demografik mendapatkan bahwa pada 170 subjek penelitian ditemukan 134 subyek $(78,8 \%)$ mengalami keluhan umum dari MSD pada ekstremitas atas yang tidak terspesifikasi akibat penggunaan aktif dari telepon cerdas sedangkan 36 subyek $(21,2 \%)$ lainnya tidak memiliki riwayat keluhan. Hasil modified NMQ mendapatkan bahwa keluhan MSD yang paling sering muncul ialah keluhan pada leher $(42,9 \%)$, bahu $(35,9 \%)$, dan jari tangan $(28,8 \%)$ dengan karakteristik nyeri yang paling sering ditemukan dalam setiap keluhan MSD ialah nyeri ringan (mild pain).

Tabel 3 memperlihatkan hasil uji korelasi Spearman dari karakteristik penggunaan telepon cerdas, yaitu frekuensi, durasi penggunaan dalam satu sesi, dan durasi penggunaan dalam satu hari dengan berbagai keluhan MSD yang dialami dalam 7 hari terakhir yang telah dilaporkan. Hasil uji tersebut mendapatkan hubungan bermakna antara MSD pada leher dengan frekuensi bermain permainan/gaming $(\mathrm{p}=0,04<0,05)$ dan adanya hubungan sangat bermakna antara MSD pada lengan atas dan durasi bermain permainan/gaming dalam satu sesi $(\mathrm{p}=0,005<0,01)$.

Tabel 1. Karakteristik umum subjek penelitian $(\mathrm{N}=170)$

\begin{tabular}{llcc}
\hline & Karakteristik & Frekuensi (n) & Persentase (\%) \\
\hline Jenis kelamin & Laki-laki & 63 & 37,1 \\
& Perempuan & 107 & 62,9 \\
Aktifitas penggunaan & Memiliki aktivitas gaming & 135 & 79,5 \\
telepon cerdas & Tidak memiliki aktivitas gaming & 35 & 20,5 \\
\hline
\end{tabular}


Tabel 2. Deskripsi statistik aktivitas penggunaan telepon cerdas subjek penelitian ( $\mathrm{N}=170)$

\begin{tabular}{llccccc}
\hline & & $\begin{array}{c}\text { Penggunaan } \\
\text { Min. }\end{array}$ & $\begin{array}{c}\text { Penggunaan } \\
\text { Maks. }\end{array}$ & Rerata & $\begin{array}{c}\text { Standar } \\
\text { Deviasi }\end{array}$ & n \\
\hline Aktivitas & Frekuensi (kali/hari) & 1 & 10 & 2,9 & 1,692 & \\
gaming & $\begin{array}{l}\text { Durasi dalam satu sesi } \\
\text { (jam) }\end{array}$ & 0,08 & 5 & 1,6 & 1,05980 & 135 \\
& Durasi total sehari (jam) & 0,25 & 15 & 4,5 & 3,37575 & \\
\hline
\end{tabular}

Tabel 3. Uji korelasi Spearman antara aktivitas bermain permainan/gaming dengan keluhan MSD pada ekstremitas atas dalam 7 hari terakhir $(\mathrm{N}=170)$

\begin{tabular}{|c|c|c|c|c|c|}
\hline \multirow[t]{2}{*}{ MSD } & \multirow{2}{*}{\multicolumn{2}{|c|}{$\mathrm{n}(\%)$}} & $\begin{array}{l}\text { Frekuensi } \\
\text { gaming }\end{array}$ & $\begin{array}{c}\text { Durasi gaming } \\
\text { satu sesi }\end{array}$ & $\begin{array}{c}\text { Durasi gaming } \\
\text { satu hari }\end{array}$ \\
\hline & & & \multirow{3}{*}{$0,158(0,040)^{*}$} & \multicolumn{2}{|l|}{$\mathrm{r}($ nilai $\mathrm{p})$} \\
\hline \multirow{2}{*}{ Leher } & Tidak & $97(57,1 \%)$ & & $-0,006(0,938)$ & $0,085(0,269)$ \\
\hline & $\begin{array}{l}\text { Ya } \\
\text { Tidak }\end{array}$ & $\begin{array}{c}73(42,9 \%) \\
109(64,1 \%)\end{array}$ & & \multirow[b]{2}{*}{$0,072(0,348)$} & \multirow[b]{2}{*}{$0,078(0,315)$} \\
\hline Bahu & $\mathrm{Ya}$ & $61(35,9 \%)$ & $0,141(0,067)$ & & \\
\hline Lengan atas & $\begin{array}{l}\text { Tidak } \\
\text { Ya }\end{array}$ & $\begin{array}{c}132(77,6 \%) \\
38(22,4 \%)\end{array}$ & $0,095(0,219)$ & $0,213(0,005)^{* *}$ & $0,142(0,065)$ \\
\hline Siku & $\begin{array}{l}\text { Tidak } \\
\text { Ya }\end{array}$ & $\begin{array}{c}151(88,8 \%) \\
19(11,2 \%)\end{array}$ & $0,089(0,249)$ & $0,048(0,535)$ & $0,024(0,759)$ \\
\hline Lengan bawah & $\begin{array}{l}\text { Tidak } \\
\text { Ya }\end{array}$ & $\begin{array}{c}149(87,6 \%) \\
21(12,4 \%)\end{array}$ & $0,034(0,655)$ & $0,036(0,643)$ & $0,027(0,731)$ \\
\hline \multirow{2}{*}{ Pergelangan tangan } & Tidak & $123(72,4 \%)$ & \multirow{2}{*}{$0,062(0,425)$} & \multirow{2}{*}{$0,101(0,192)$} & \multirow{2}{*}{$0,055(0,479)$} \\
\hline & $\mathrm{Ya}$ & $47(27,6 \%)$ & & & \\
\hline Jari tangan & $\begin{array}{l}\text { Tidak } \\
\text { Ya }\end{array}$ & $\begin{array}{c}121(71,2 \%) \\
49(28,8 \%)\end{array}$ & $0,150(0,051)$ & $0,207(0,007)^{* *}$ & $0,156(0,042)^{*}$ \\
\hline
\end{tabular}

Selain itu, terdapat juga hubungan yang sangat bermakna antara keluhan MSD pada jari tangan dengan durasi bermain permainan/gaming satu sesi $(\mathrm{p}=0,007<0,01)$ dan durasi bermain permainan/gaming dalam satu hari $(\mathrm{p}=0,042<0,05)$.

\section{BAHASAN}

Musculoskeletal disorders dapat terjadi oleh karena beberapa faktor risiko, yaitu faktor fisik, factor biomekanik, faktor individu, maupun faktor-faktor yang berhubungan dengan faktor sosial lainnya. Postur tubuh, gerakan berulang/repetitif, kekuatan yang dikeluarkan (force), durasi, frekuensi, dan vibrasi merupakan hal yang berpotensi untuk menyebabkan MSD dari segi faktor fisik dan biomekanik, ${ }^{12,13}$ sedangkan faktor invidu yaitu jenis kelamin, usia dan IMT dapat memengaruhi kemunculan MSD pada seorang individu. ${ }^{14,15}$
Publikasi systematic review dari Toh et $\mathrm{al}^{16}$ di tahun 2017 menjelaskan bahwa kegiatan yang dapat dilakukan pada perangkat seluler dengan layar sentuh, termasuk di dalamnya telepon cerdas, dapat dibagi dua yaitu aktifitas aktif maupun aktifitas pasif. Aktivitas aktif dianggap sebagai aktifitas yang dapat dilakukan secara aktif yang memerlukan adanya gerakan jari-jari secara sering seperti mengetik maupun saat sedang bermain permainan/gaming. Aktivitas aktif secara umum dapat berhubungan dengan adanya postur dan aktivitas otot yang tidak netral dari kepala, leher dan ekstremitas atas yang berada dari distal tubuh sedangkan, aktifitas pasif dianggap sebagai aktifitas yang hanya terdiri dari aktivitas visual saja dengan tanpa atau gerakan minimal dari jari tangan. ${ }^{16}$

Pada prevalensi keluhan MSD di ekstremitas atas yang dialami dalam 7 hari 
terakhir dari subjek penelitian terlihat bahwa $78,8 \%$ memiliki keluhan MSD secara umum dari ekstremitas atas. Jika dilihat keluhan MSD yang dirasakan pada area organ spesifik dari ekstremitas atas, keluhan pada leher $(42,9 \%)$, bahu $(35,9 \%)$, dan jari tangan $(28,8 \%)$ merupakan keluhan MSD yang paling sering muncul pada subjek penelitian.

Berolo et al ${ }^{10}$ melaporkan bahwa $98 \%$ dari total 140 orang yang menjadi subjek penelitiannya menggunakan perangkat genggam seluler, termasuk di dalamnya telepon cerdas. Terdapat $84 \%$ dari subjek penelitian setidaknya memiliki 1 keluhan MSD pada organ tertentu. Keluhan MSD yang muncul pada penelitian ini tanpa melihat karakteristik nyeri yang muncul ialah keluhan MSD pada leher (68\%), punggung belakang (62\%), bahu kanan (52\%), bahu kiri (46\%), lengan kanan $(32 \%)$, dan lengan kiri (27\%). Keluhan pada ibu jari dari masing-masing tangan kiri dan tangan kiri merupakan bagian dari tangan yang paling banyak dirasakan adanya keluhan. Penelitian Lui et al ${ }^{17}$ pada pelajar sekolah dasar dengan rentang umur 8-13 tahun melaporkan bahwa dari 476 pelajar, 97,5\% secara aktif bermain permainan/ gaming dengan perangkat gaming portabel, termasuk di dalamnya ponsel. Tiga keluhan MSD yang paling sering dilaporkan pada penelitian ini ialah keluhan MSD pada leher $(28,15 \%)$, bahu $(19,3 \%)$, dan jemari tangan $(10,71 \%)$. Kim dan $\mathrm{Kim}^{6}$ meneliti mahasiswa kesehatan gigi dengan 292 subjek penelitian yang sahih, dan mendapatkan bahwa $42,5 \%$ menggunakan telepon cerdas untuk bertukar pesan dan $12,5 \%$ menggunakannya untuk bermain permainan/gaming. Pada penelitian tersebut didapatkan keluhan MSD pada leher $(55,8 \%)$, bahu $(54,8 \%)$, pinggang $(29,8 \%)$ dan jari tangan $(19,9 \%)$ merupakan empat keluhan yang paling sering muncul.

Balakrishnan et $\mathrm{al}^{7}$ melakukan penelitian pada 200 mahasiswa berusia 18-30 tahun yang menggunakan perangkat genggam elektronik. Keluhan MSD yang muncul akibat penggunaan perangkat genggam elektronik termasuk telepon cerdas yaitu
44,5\% subjek penelitian mengalami nyeri ringan (mild), 24,5\% memiliki nyeri sedang (moderate), 3,5\% mengalami nyeri hebat (worst possible pain), dan $27,5 \%$ tidak mengalami adanya nyeri.

Yang et $\mathrm{al}^{8}$ meneliti 302 pelajar sekolah lanjutan di Taiwan yang memiliki rentang usia dari 16 tahun sampai $>19$ tahun, dan mendapatkan bahwa 56\% menghabiskan waktu 1-3 jam dalam sehari untuk bertukar pesan dan 55,6\% menghabiskan waktu 1-3 dalam sehari untuk menggunakan fungsi tambahan lain dari telepon cerdas, termasuk di dalamnya untuk bermain permainan/ gaming. Selain itu, $56,6 \%$ pelajar tersebut juga menghabiskan lebih dari 3 jam waktu mereka di akhir pekan untuk menggunakan telepon cerdas tanpa melihat aktivitas spesifik yang dilakukan. Keluhan MSD dalam 6 bulan terakhir yang dilaporkan terbanyak merupakan keluhan MSD pada leher $(52 \%)$, bahu $(46,4 \%)$, dan punggung belakang $(37,4 \%)$, sedangkan hanya $16,2 \%$ subjek penelitian yang memiliki keluhan pada pergelangan maupun jari tangan.

Terdapat beberapa perbedaan karakteristik subjek penelitian dari penelitian yang dilakukan penulis dan penelitianpenelitian yang telah disebutkan; salah satunya ialah rentang usia subjek penelitian yang didapatkan. Penulis belum dapat menemukan penelitian lain yang memiliki subjek penelitian dengan rentang usia yang sama, namun hasil prevalensi keluhan MSD yang muncul dapat dikatakan cukup sesuai dengan hasil berbagai penelitian sebelumnya. Pada berbagai penelitian tersebut, prevalensi keluhan MSD di daerah leher, bahu, dan jari tangan yang muncul akibat penggunaan telepon cerdas maupun perangkat genggam seluler yang lain merupakan keluhan MSD yang paling banyak dilaporkan, yang sejalan dengan prevalensi yang didapatkan penulis pada penelitian ini. Hal ini juga mendukung pernyataan Doda ${ }^{18}$ yaitu leher dan bahu merupakan organ tubuh yang paling sering mengalami nyeri dan ketidaknyaman musculoskeletal.

Pada penelitian ini, keluhan MSD secara umum tanpa melihat organ spesifik dari ekstremitas atas memiliki hubungan 
bermakna dengan frekuensi aktivitas bermain permainan/gaming $(\mathrm{p}=0,017<0,05)$ Pada keluhan MSD yang dirasakan dalam 7 hari terakhir, keluhan daerah leher didapatkan memiliki hubungan bermakna dengan frekuensi bermain permainan/ gaming dan frekuensi satu sesi bertukar pesan $(p=0,040<0,05)$. Keluhan MSD pada lengan atas serta jari tangan juga mempunyai hubungan yang sangat bermakna dengan durasi bermain permainan/gaming satu sesi $(\mathrm{p}=0,005<0,01$ dan $\mathrm{p}=0,007<0,01)$. Selanjutnya, terdapat juga hubungan yang sangat bermakna antara keluhan MSD pada jari tangan dengan durasi bermain permainan/gaming dalam satu sesi $(\mathrm{p}=0,007<0,01)$ dan hubungan bermakna antara keluhan MSD pada jari tangan dengan durasi bermain permainan/gaming dalam dalam sehari $(\mathrm{p}=0,042<0,05)$.

Lui et $\mathrm{al}^{17}$ mendapatkan adanya hubungan bernakna antara penggunaan perangkat dengan layar kecil, termasuk di dalamnya telepon genggam, dan keluhan MSD pada leher dan ekstremitas atas $(\mathrm{p}<0,01<0,05)$. Berolo et $a l^{10}$ melaporkan adanya hubungan bermakna antara durasi bermain permainan/gaming di telepon cerdas dengan nyeri pada bahu kanan dan ibu jari tengah $(\mathrm{p}<0,05)$, serta adanya hubungan antara durasi waktu bertukar pesan dan nyeri moderate dan severe pada bahu kanan $(\mathrm{p}<0,05)$. Sebaliknya, Kim dan $\mathrm{Kim}^{6}$ tidak mendapatkan adanya hubungan bermakna antara periode waktu penggunaan telepon cerdas dengan berbagai keluhan MSD pada ekstremitas atas. Demikian pula Yang et $\mathrm{al}^{5}$ tidak mendapatkan adanya hubungan antara aktivitas bertukar pesan maupun aktivitas penggunaan fungsi tambahan di telepon cerdas dengan berbagai keluhan MSD pada leher dan ekstremitas, namun mereka mendapatkan adanya hubungan antara durasi waktu penggunaan telepon cerdas pada hari di akhir pekan dengan keluhan MSD pada lengan.

Hasil uji korelasi penulis masih sejalan dengan penelitian Berolo et $\mathrm{a}^{10}$ dan Yang et $\mathrm{al}^{5}$. Hubungan antara keluhan MSD pada leher dan frekuensi bermain permainan/ gaming maupun bertukar pesan $(p<0,05)$ juga masih sejalan dengan hasil penelitian Lui et al. ${ }^{17}$ Walaupun demikian, hasil uji korelasi yang dilakukan penulis berbeda dengan hasil penelitian Kim dan $\mathrm{Kim}^{6}$ yang tidak mendapatkan adanya hubungan antara penggunaan telepon cerdas dengan keluhan MSD pada ekstremitas atas.

Penelitian-penelitian yang telah dipaparkan tidak melibatkan frekuensi atau banyaknya sesi dalam satu dari aktivitas bermain permainan/gaming dengan aktivitas bertukar pesan. Pada systematic review oleh Xie et $\mathrm{al}^{19}$ yang juga mengevaluasi beberapa publikasi sebelumnya melaporkan bahwa peserta penelitian yang mengalami keluhan MSD memiliki frekuensi panggilan telepon, bertukar pesan dan gaming yang lebih banyak dari yang tidak memiliki keluhan MSD. Walaupun menurut Xie et al ${ }^{19}$ masih diperlukan penelitian yang lebih lanjut untuk mendapatkan apakah benar terdapat hubungan yang lebih konkrit antara frekuensi aktivitas panggilan telepon, bertukar pesan dan bermain permainan/gaming, uji statistik penulis menunjukkan bahwa terdapat hubungan bermakna antara frekuensi aktivitas bermain maupun bertukar pesan dengan MSD pada leher dan bahu.

$\mathrm{Toh}^{16}$ dalam penelitiannya menegaskan bahwa penggunaan aktif dari telepon cerdas secara umum dapat menyebabkan postur tidak netral dan lebih banyak aktivitas otot sepanjang kepala, leher, bahu, pergelangan tangan dan jemari pada tangan, yang diduga dapat lebih memperbesar paparan pada risiko stres biomekanikal jika dibandingkan dengan penggunaan pasif telepon cerdas. Toh $^{16}$ juga mendapatkan bahwa ukuran layar dapat memengaruhi paparan dari keluhan MSD, ditambah dengan berat telepon cerdas itu sendiri dan posisi telepon genggam saat digunakan. Memegang perangkat dengan layar yang lebih besar dapat memicu keluhan pada bahu dan lengan. Demikian pula memegang perangkat dengan satu tangan diduga dapat memperbesar paparan keluhan MSD pada lengan, jemari terkhususnya ibu jari jika dibandingkan dengan memegang perangkat dengan kedua tangan. Postur tubuh dengan fleksi leher menetap yang sering dilakukan 
oleh para pengguna diduga merupakan salah satu faktor utama yang dapat menjelaskan adanya prevalensi yang tinggi dari keluhan pada leher. ${ }^{20}$ Menurut Gustaffson et al, ${ }^{9}$ tangan dan jari merupakan organ yang paling sering terpapar ketika melakukan aktivitas bertukar pesan sehingga adanya keluhan MSD pada tangan dan jari khususnya pada ibu jari dianggap dapat terjadi karena adanya pergerakan repetitif dari ibu jari. Penulis berasumsi bahwa keluhan MSD yang paling banyak muncul pada prevalensi MSD yang dialami dalam 7 hari terakhir serta adanya hubungan antara keluhan MSD dengan durasi maupun frekuensi penggunaan telepon cerdas selaras dengan berbagai teori yang telah diungkapkan.

\section{SIMPULAN}

Pada remaja pelajar SMA, prevalensi MSD di ekstremitas atas yang dialami dalam 7 hari terakhir akibat penggunaan telepon cerdas secara aktif sebesar $78,8 \%$, paling sering di daerah leher, dengan karakteristik nyeri ringan. Frekuensi dan durasi penggunaan telepon cerdas berpengaruh terhadap timbulnya keluhan MSD pada ekstremitas atas.

Bagi peneliti lanjut, disarankan untuk meneliti aktivitas dan pola penggunaan telepon cerdas dengan keluhan MSD pada populasi lainnya dengan jumlah subjek penelitian yang lebih besar sehingga bisa didapatkan hasil yang lebih akurat. Juga dapat ditambahkan faktor risiko lainnya yaitu, postur dan posisi tubuh saat menggunakan telepon cerdas, serta penelitian untuk membuktikan bahwa waktu istirahat saat menggunakan telepon cerdas dapat memengaruhi maupun mengurangi keluhan MSD yang muncul.

Penulis menyatakan tidak terdapat konflik kepentingan dalam studi ini.

\section{Konflik Kepentingan}

Penulis menyatakan tidak terdapat konflik kepentingan dalam studi ini.

\section{DAFTAR PUSTAKA}

1. Kaonang G. Daily Social. [Online]. 2016 [cited 2019 Aug 24]. Available from: https://dailysocial.id/post/memahamitren-penggunaan-smartphone-diindonesia-berdasarkan-usia.

2. Pew Research Center. Teens, Social Media \& Technology 2018. [Online].; 2018 [cited 2019 Sept 11]. Available from: https://www.pewresearch.org/internet /2018/05/31/teens-social-mediatechnology-2018/.

3. Statista Research Department. Statista. [Online].; 2016 [cited 2019 Aug 23]. Available from: https://www.statista. com/statistics/805090/us-smartphoneusers-by-age-group/.

4. Nath A, Mukherjee S. Impact of mobile phone/smartphone: a pilot study on positive and negative effects. IJARCSMS. 2015;3(5):295-302.

5. Yang SY, Chen MD, Huang YC, Lin CY, Chang JH. Association between smartphone use and musculoskeletal discomfort in adolescent students. J Community Health. 2017;42(3):423-30.

6. Kim HJ, Kim JS. The relationship between smartphone use and subjective musculoskeletal symptoms and university students. J Phys Ther Sci. 2015;27(3): 575-9.

7. Balakrishnan R, Chinnavan E, Feii T. An extensive usage of hand held devices will lead to musculoskeletal disorder of upper extremity among student in AMU: A survey method. International Journal of Physical Education, Sports and Health. 2016;3(2):368-72.

8. Eapen C, Kumar B, Bhat AK. Prevalence of cumulative trauma disorder in cell phone users. J Musculoskelet Res. 2010; 13:137-43.

9. Gustaffson E, Johson PW, Hegberg M. Thumb postures and physical loads during mobile phone use - A comparison of young adults with and without musculoskeletal symptoms. J Electromyogr Kinesial. 2010;20:127-35.

10. Berolo S, Wells RP, Amick III BC. Musculoskeletal symptoms among mobile hand-held device users and their relationship to device use: A preliminary study in a Canadian university population. Appl Ergon. 2011;42(2):371-8.

11. López-Aragón L, López-Liria R, CallejónFerre ÁJ, Gómez-Galán M. Applications of the standardized Nordic questionnaire: A review. Sustainability. 
2017;9(9):1514.

12. Korhan O, Memon AA. Introductory Chapter: Work-related musculoskeletal disorders. In Korhan O, editor. Workrelated Musculoskeletal Disorder. IntechOpen, 2019; p. 1-10.

13. Hales TR, Bernard BP. Epidemiology of work-related musculoskeletal disorders. The orthopedic Clinics of North America. 1996;27(4):679-709.

14. Collins JD, O'Sullivan LW. Musculoskeletal disorder prevalence and psychosocial risk exposures by age and gender in a cohort of office based employees in two academic institutions. International Journal of Industrial Ergonomics. 2015; 46:85-97.

15. Tantawy SA, Rahman AA, Ameer MA. The relationship between the development of musculoskeletal disorders, body mass index, and academic stress in Bahraini University students. Korean J Pain. 2017;30(2):126-33.

16. Toh SH, Coenen P, Howle EK, Straker LM.
The associations of mobile touch screen device use with musculoskeletal symptoms and exposures: A systematic review. PLOS ONE. 2017;12(8): e0181220.

17. Lui DPY, Szeto GPY, Jones AYM. The pattern of electronic game use and related bodily discomfort in Hong Kong primary school children. Computers \& Education. 2011;57:1665-74.

18. Doda DVD. Prevention of musculoskeletal pain and discomfort in South Australian workplaces: Evaluation of a stage of change approach [Thesis]. South Australia: University of Adeleide; 2014.

19. Xie Y, Szeto G, Dai J. Prevalence and risk factors associated with musculoskeletal complaints among users of mobile handheld devices: A systematic review. Applied Ergonomics. 2017;59:132-42.

20. Werth A, Babski-Reeves K. Effects of portable computing devices on posture, muscle activation levels and efficiency. Applied Ergonomics. 2014;45(6):1603-9. 